\title{
PERANCANGAN ULANG TURBIN KAPLAN POROS VERTIKAL DI PLTM PLUMBUNGAN
}

\author{
Rudi Saputra1, Taff Liichan ${ }^{2}$ \\ 1, 2 Program Studi Teknik Mesin, Institut Sains dan Teknologi Nasional, Jakarta Selatan \\ Email: rudisaputra@yahoo.com
}

\begin{abstract}
Hydroelectric Power Plants (PLTA) in Indonesia have been around since 1926, and are still operating today. The Indonesian government represented by PT. PLN (State Electricity Company) will continue to maintain, operate and maintain old hydropower plants. So far, the development and development of PLTMH in Indonesia still uses consultants / contractors and its manufacturing is from overseas, even components (spare parts) are also still dependent on the technology producers themselves, the majority of which are foreign countries. Imports cannot be avoided, this results in us being vulnerable to several things, fluctuations in foreign exchange rates, and dependence on foreign producers. But with the increasing understanding of national resilience, especially in terms of national industrial independence, several national companies began to carry out reconstruction and fabrication for hydroelectric power plants. This is encouraging the author to learn to know, understand, how to plan the main parts of the Kaplan Turbine which include: runner, shaft, spiral casing, stacker, draft tube. In this plan the author focuses on calculating the main dimensions of the Kaplan Turbine. From the results of the design and calculation, the appropriate type of turbine is Kaplan Turbine as an electric generator drive in Plumbungan PLTM with installed power of $1.2 \mathrm{MW}$, maximum head of 21.16 meters and water discharge requirement of $7.68 \mathrm{~m} 3 / \mathrm{sec}$. Plumbungan PLTM installation consists of turbines, turbine supporting equipment, and turbine operation aids. The turbine installation component consists of: suction pipe (penstock), turbine house (spiral casing), runner, runner shaft, shaft support bearing and draft tube.
\end{abstract}

Keywords: Kaplan Turbine, Head, Power Turbine, Runner, Plumbungan PLTM Turbine Caplane

\section{PENDAHULUAN}

\section{Latar Belakang Masalah}

Pembangkit Listrik Tenaga Air (PLTA) di Indonesia sudah ada sejak tahun 1926, dan sampai saat ini masih tetap beroperasi. Pemerintah Republik Indonesia yang di wakili PT. PLN (Perusahaan Listrik Negara) masih akan terus merawat, mengoperasikan dan mempertahankan PLTA yang sudah tua, jika dilihat dari sisi masa pengoperasiannya. Selain untuk memanfaatkan secara optimal ketersedian potensi energi baru terbarukan yang murah dan ramah lingkungan, yaitu air yang begitu melimpah di Indonesia, juga sebagai salah satu upaya nyata dari PLN untuk meningkatkan rasio energy feul mix.

Dalam upaya menambah kapasitas produksi energi listrik di Indonesia khususnya Jawa Tengah, PT Indonesia Power Unit Pembangkit Bisnis Mrica mengembangkan Pembangkit Listrik Tenaga Mikro Hidro (PLTMH). Listrik yang dihasilkan juga dapat langsung digunakan untuk memenuhi kebutuhan listrik di setiap jaringan distribusi listrik PT PLN setempat, atau tidak masuk ke dalam jaringan listrik Jawa-Bali, sekarang ini baru tiga lokasi yang mulai digarap untuk pembangunan PLTMH, yakni di Banjarnegara dan Banyumas. Selebihnya, ada delapan lokasi yang masih dalam uji kelayakan.

Selama ini pembangunan dan pengembangan PLTMH di Indonesia masih menggunakan konsultan / kontraktor dan pabrikasinya berasal dari luarnegri, bahkan komponen-komponen (spare parts) juga masih tergantung dari produsen teknologi itu sendiri yang mayoritas adalah negaranegara asing. Impor tidak dapat dihindari, hal ini mengakibatkan kita rentan terhadap beberapa hal, fluktuasi nilai tukar mata uang asing, dan ketergantungan terhadap produsen luar negeri. Akan tetapi dengan semakin meningkatnya pemahaman mengenai ketahanan nasional, khususnya dalam hal kemandirian industry nasional, beberapa perusahaan nasional mulai melakukan rekonstruksi dan pabrikasi untuk pembangkit listrik tenaga air. Hal ini lah mendorong penulis untuk mengetahui, memahami, mempelajari bagaimana merencanakan 
bagian-bagian utama Turbin Kaplan yang antara lain: runner, poros, spiral casing, penstok, draft tube. Dalam perencanaan ini penulis menitik beratkan pada perhitungan dimensi utama pada Turbin Kaplan.

\section{Pokok Masalah}

Berdasarkan latar belakang diatas, dapat dirumuskan permasalahan yang dijadikan kajian studi atau penelitian ini adalah "Perencanaan Ulang Turbin Kaplan Poros Vertikal di PLTM Plumbungan", hal ini sangat perlu dilakukan mengingat di daerah tersebut masih perlu pengembangan dari yang sudah ada, dan data-data pendukung yang diperoleh sangat terbatas.

\section{Batasan Masalah}

Perencanaan Turbin Kaplan Poros Vertikal sangat luas, pada kesempatan ini agar tidak bias maka penulis membatasinya pada perhitunganperhitungan:

1.Perhitungan dimensi utama turbin Kaplan poros vertical dengan Ketinggian (head) maksimal 21,16 meter.

2.Perhitungan Pipa pesat (Penstok).

3.Perhitungan Rumah Siput (spiral cashing).

4.Perhitungan Pipa isap (draft tube).

5.Perhitungan Poros dan Bantalan.

\section{Tujuan dan Manfaat}

Pembahasan masalah pada skripsi ini adalah merencanakan ulang turbin Kaplan poros vertical di PLTM Plumbungan yang bertujuan untuk meningkatkan efisiensi dari turbin tersebut.

Perancangan dan pengujian turbin Kaplan ini diharapkan akan memberikan manfaat diantaranya adalah sebagai berikut :

1. Memperluas pengetahuan bahwa waduk Plumbungan dapat dimanfaatkan untuk pembangkit energi listrik.

2. Memperluas pengetahuan khususnya masyarakat sekitar waduk Plumbungan tentang bagaimana perancangan jenis Turbin Kaplan yang dapat diterapkan di waduk tersebut.

3. Menambah suplai pasokan energi listrik untuk daerah sekitar waduk.

\section{LANDASAN TEORI}

\section{Dasar Teori Turbin Air}

Kata "Turbine" dikemukakan oleh seorang insinyur dari Perancis yang bernama Claude Bourdin pada awal abad ke 19, yang diambil dari terjemahan bahasa latin dari kata "Whirling" (putaran) atau "Vortex" (pusaran air). Perbedaan dasar antara turbin awal dengan kincir air adalah komponen putaran air yang memberiakan energi pada poros yang berputar. Komponen tambahan ini memungkinkan turbin dapat memberikan daya yang lebih besar pada komponen yang lebih kecil. Turbin dapat memanfaatkan air dengan putaran yang lebih cepat dan dapat memanfaatkan head yang lebih tinggi.

Jenis-jenis turbin yang digunakan hidroelektrik pada saat ini adalah:

1. Turbin Francis (1849)

2. Turbin Pelton (1889)

3. Turbin Baling-baling dan Kaplan (1913)

4. Turbin Deriaz (1945)

Secara umum komponen-komponen yang terdapat pada turbin pada turbin air hampir sama, hanya saja yang membedakan adalah pengeraknya saja.

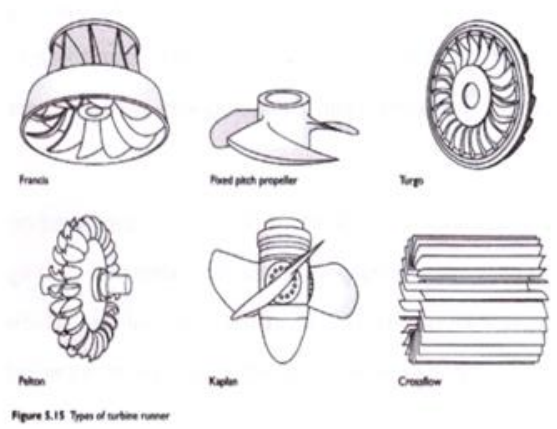

Gambar 1. Pengerak-Pengerak Pada Turbin

Pada turbin baling-baling (propeller) dengan turbin Kaplan, kedua turbin tersebut mempunyai kesamaan secara hidrolik. Terkecuali turbin Kaplan yang mempunyai susunan tambahan guna disesuaikan dengan kecondongan bilah penggerak (runner) atau baling-baling. Hal ini secara koperatif akan memberikan efisiensi yang tinggi bahkan dalam kondisi beban sebagian.

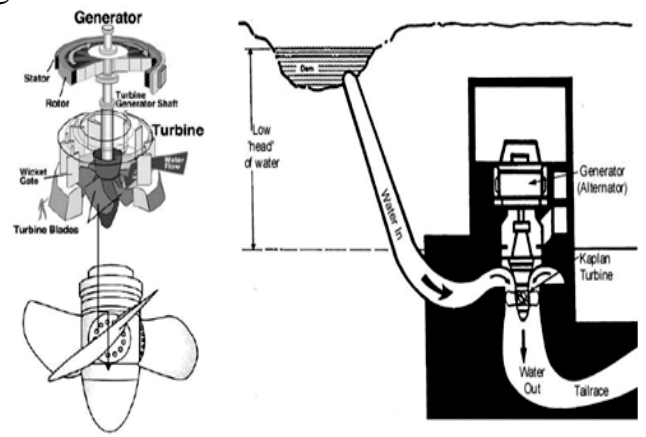

Penggerak (runner) secara geometris berbeda setiap jenis turbinya. Penggerak dilindungin oleh kerangka yang juga memuat mekanisme pengatur yang mengatur air dari batang pipa ke penggerak. Mekanisme pengatur ini juga tergantung dari jenis turbin, terkecuali turbin Pelton yang yang 
pada semua turbin kerangkanya berfungsi hidrolik dan desainnya sama penting dengan desain penggerak.

\section{Bagian - Bagian Turbin Kaplan}

Turbin Kaplan yang ada di PLTM Plumbungan dilaksanakan dengan poros vertikal. Turbin dikopel ke rotor generator oleh sebuah poros. Putaran poros turbin searah jarum jam jika dilihat dari atas. Semua masa turbin berputar ditopang sepenuhnya oleh bantalan aksial generator.

Bagian - bagian utama turbin terdiri dari:

1. Rumah turbin (Casing)

2. Sudu Hantar (Guide vane)

3. Sudu jalan (Runner)

4. Poros utama ( main shaft)

5. Bantalan (Guide bearing)

6. Batalan Aksial (Thrust bearing)

7. Pipa isap ( draft tube )

\section{Persamaan Energi}

Persamaan energi pada titik pemasukan dan pengeluaran dapat dinyatakan sebagai berikut (Sumber: Dandekar \& Sharman, 1979, hal: 430):

$$
\frac{P_{1}}{\gamma}+\frac{V_{r 1}^{2}}{2 . g}+z_{1}=\frac{P_{2}}{\gamma}+\frac{V_{r 2}^{2}}{2 . g}+z_{2}+\frac{u_{1}^{2}}{2 . g}-\frac{u_{2}^{2}}{2 . g}+h_{L}
$$

Ada dua buah perubahan dalam persamaan ini seperti dibandingkan dengan persamaan konvensional Bernouli. Pertama, kecepatan relative dipergunakan pada tempat kecepatan mutlak kedua. Ada suatu batas energi sehubungan dengan tinggi tekan sentrifugal $\frac{u_{1}{ }^{2}}{2 . g}-\frac{u_{2}{ }^{2}}{2 . g}$ ditambah mengoreksi putasan batas. $\mathrm{H}_{\mathrm{L}}$ menyatakan kehilangan tinggi tekan sehubungan dengan gesekan dayung. Umumnya $\left(\mathrm{z}_{1}-\mathrm{z}_{2}\right)$ adalah bersifat tidak berarti dan oleh sebab itu diabaikan, jadi setelah penulisan kembali (Sumber: Dandekar \& Sharman, 1979, hal: 430):

$$
\frac{P_{1}-P_{2}}{\gamma}=\frac{V_{r 1}{ }^{2}-V_{r 2}^{2}}{2 . g}+\frac{u_{1}^{2}-u_{2}^{2}}{2 . g}+h_{L}
$$

Yang dapat dinyatakan sebagai:

$$
h=\frac{P_{1}-P_{2}}{\gamma}+\frac{V_{r 1}{ }^{2}-V_{r 2}{ }^{2}}{2 . g}=\frac{V_{r 1}{ }^{2}-V_{r 2}{ }^{2}}{2 . g}+\frac{u_{1}{ }^{2}-u_{2}{ }^{2}}{2 . g}+\frac{V_{r 2}{ }^{2}-V_{r 1}{ }^{2}}{2 . g}+h_{L}
$$

Merupakan pernyataan untuk penekanan berlebih (over pressure) dalam turbin-turbin Francis. Untuk turbin Kaplan ada penyederhanaan lebih lanjut untuk memberikan kemampuan $\mathrm{u}_{1}=\mathrm{u}_{2}$. Selajutnya persamaannya menjadi:

$$
\frac{P_{1}-P_{2}}{\gamma}=\frac{V_{r 2}{ }^{2}-V_{r 1}^{2}}{2 . g}+h_{L}
$$

Untuk membandingkan dua persamaan, jumlah dari tekanan lebih pada turbin-turbin Kaplan kurang dari nol. Untuk turbin Pelton, tekanan lebih adalah nol, selanjutnya persamaan berubah menjadi (Sumber: Dandekar \& Sharman, 1979, hal: 431):

$$
\frac{V_{r 2}^{2}}{2 . g}=\frac{V_{r 1}^{2}}{2 \cdot g}+h_{L}
$$

atau

$$
V_{r 2}=K \cdot V_{r 1}
$$

Keterangan $\mathrm{K}$ adalah faktor koreksi dari kehilangan geseran dari dayung dan mempunyai harga dari 0,90-0,95.

\section{Persamaan Momentum}

Persamaan momentum merupakan kunci persamaan turbin, juga terkenal sebagai persamaan turbin dari Euler. Sehubungan hal itu :

- Tenaga Putaran = rata-rata perubahan momentum dari aliran zat cair.

- Tenaga kerja = tenaga putaran $\mathrm{x}$ perubahan sudut.

- Kerja perdetik = tenaga putara $\mathrm{x}$ kecepatan angular.

Bagaimanapun juga jika tenaga putaran dapat dihitung kerja yang dilakukan oleh air dalam turbin dapat dinyatakan oleh sebuah formula. Sekarang, masa dari yang mengalir adalah (Sumber:Dandekar \& Sharman, 1979, hal: 432):

$$
\text { Perdetik }=\frac{\gamma \cdot \boldsymbol{Q}}{g}
$$

Jadi, momentum dari air yang mengalir masuk dalam arah tangensial perdetik, adalah (Sumber:Dandekar \& Sharman, 1979, hal: 432):

$$
\frac{\gamma \cdot Q}{g} \cdot V_{u 1}
$$

Momen dari momentum adalah

(Sumber:Dandekar \& Sharman, 1979, hal: 432):

$$
\frac{\gamma \cdot \boldsymbol{Q}}{g} \cdot V_{u 1} \cdot r_{1}
$$

Sesuai dengan itu, momentum dari aliran air yang keluar dari dalam arah tangensial

(Sumber:Dandekar \& Sharman, 1979, hal: 432):

$$
\frac{\gamma \cdot Q}{g} \cdot V_{u 2}
$$

Dan momen dari momentum ini

(Sumber:Dandekar \& Sharman, 1979, hal: 432):

$$
\frac{\gamma \cdot Q}{g} \cdot V_{u 1} \cdot r_{2}
$$

Sekarang, rata-rata perubahan dari momentum angular = perubahan momen dari momentum $/$ detik (Sumber:Dandekar \& Sharman, 1979, hal: 433).

$$
\frac{\gamma \cdot Q}{g} \cdot\left(V_{u 1} \cdot r_{1}-V_{u 2} \cdot r_{2}\right)
$$

Tenaga putar

$$
=\frac{\gamma \cdot Q}{g} \cdot\left(V_{u 1} \cdot r_{1}-V_{u 2} \cdot r_{2}\right)
$$


Keterangan w adalah kecepatan angular, tetapi w. $\mathrm{r}_{1}=\mathrm{u}_{1}$ dan w. $\mathrm{r}_{2}=\mathrm{u}_{2}$

Efisiensi tinggi tekan $=$

$$
\frac{\left(V_{u 1} \cdot r_{1}-V_{u 2} \cdot r_{2}\right)}{g}
$$

Atau kerja yang dilakukan $/ \mathrm{kg}=$

$$
\frac{\left(V_{u 1} \cdot r_{1}-V_{u 2} \cdot r_{2}\right)}{g}
$$

Persamaan ini adalah persamaan umum turbin untuk semua turbin.

\section{METODE DAN PENGOLAHAN DATA \\ Diagram Alir Perancangan}

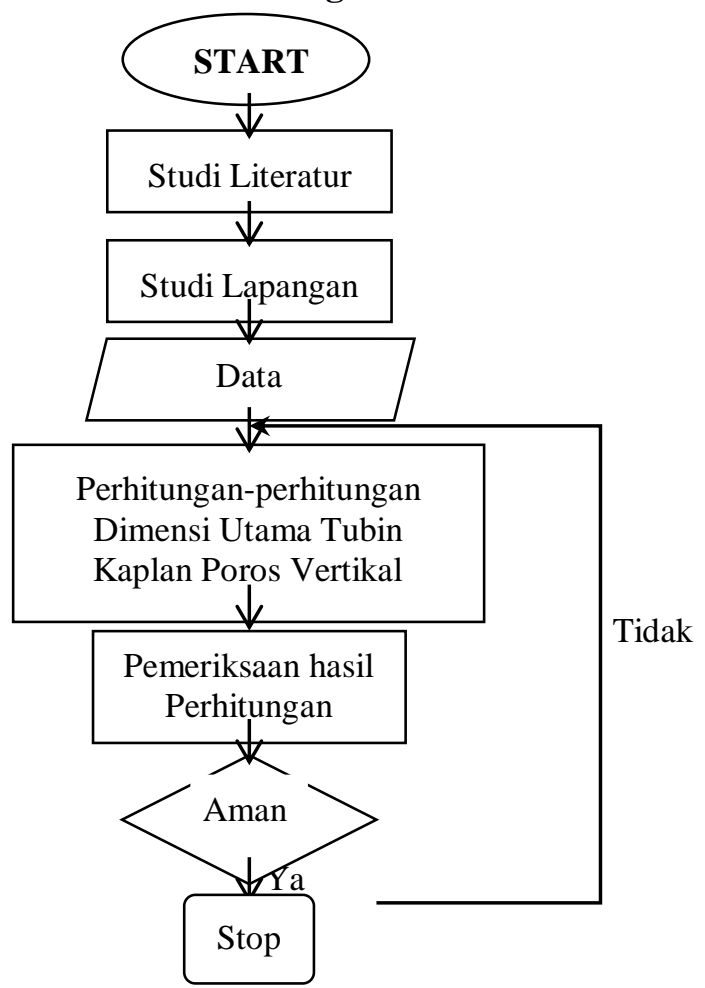

Gambar 3. Diagram alir perancangan

Panjang penstock dapat diukur dengan mengunakan pendekatan empiris, karena sudut elevasinya sekitar $15,18^{0}$, maka:

$$
\begin{aligned}
L & =\frac{Q}{\tan 15,18} \\
\mathrm{~L} & =75 \mathrm{~m}
\end{aligned}
$$

Perhitungan Head Losses Penstock

Kerugian ketinggian (head losses) pada

Penstock antara lain:

1. Head loss pada trash rach

2. Head loss pada entrance

3. Head loss akibat penyempitan pipa:

4. Head loss akibat friction

5. Head loss pada elbow

6. Head loss pada katup

Total Head loss adalah hasil penjumlahan dari head loss yang terjadi pada trash rach, entrance, elbow, valve, dan akibat penyempitan pipa dan gesekan jadi:

Head loss total $={ }_{H_{t r}}+H_{v}+H_{b}+H_{f}+H_{c}+H_{e}$

$$
H_{\text {total }}=0,805 \quad m
$$

Menghitung Kecepatan Spesifik Dan Ukuran

Utama Turbin Kaplan

i. Menghitung Kecepatan Spesifik

Untuk menghitung kecepatan spesifik digunakan persamaan (Sumber:

Dandekar \& Sharman, 1979, hal: 397) sebagai berikut:

$$
\begin{aligned}
& N_{s}=\frac{N \sqrt{Q}}{h^{3 / 4}} \\
& N_{s}=144,6 \mathrm{rpm}
\end{aligned}
$$

ii. Menghitung Ukuran Utama Dari Runner

Dari diagram harga informatif untuk menentukan ukuran-ukuran utama turbin kaplan, didapat:

$$
\begin{aligned}
& \mathrm{U}{ }^{*}=1,58 \\
& \mathrm{U}_{\mathrm{N}}{ }^{*}=0,62 \\
& \mathrm{C}_{\mathrm{m}}{ }^{*}=0,22
\end{aligned}
$$

Harga ini harus dikalikan dengan $\sqrt{2 . g . h}$ yaitu dengan:

Sehingga didapat:

$$
\begin{array}{lll}
\mathrm{U}_{1}{ }^{*} & =32,18 \mathrm{~m} / \text { detik } \\
\mathrm{D}_{1} & =1,230 \mathrm{~m} \\
\mathrm{U}_{\mathrm{N}}{ }^{*} & =13,12 \mathrm{~m} / \text { detik } \\
\mathrm{D}_{\text {Leher Poros }}(\text { Runner Bos }) \\
\mathrm{D}_{\mathrm{N}} & =\frac{60 \times U_{N}}{\pi \cdot N}=0,501 \mathrm{~m} \\
\mathrm{C}_{\mathrm{m}}{ }^{*} & =4,66 \mathrm{~m} / \text { detik }
\end{array}
$$

Jadi, dari perhitungan diatas diketahui:

Diameter runner

$\mathrm{D}_{1}=1,230 \mathrm{~m}=1230 \mathrm{~mm}$

Diameter runner bos

$\mathrm{D}_{\mathrm{n}}=0,501 \mathrm{~m}=501 \mathrm{~mm}$

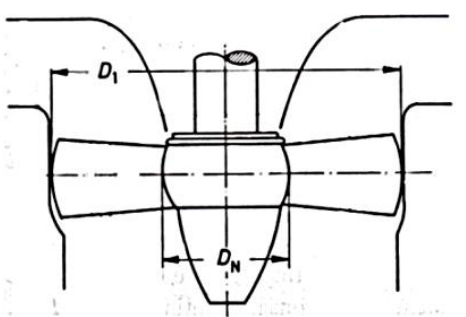

Gambar 4. Dimensi Utama Runner

Menghitung Bagian Segitiga Kecepatan

Total head loss adalah $0,805 \mathrm{~m}$ sehingga

besarnya head bersih adalah sebagai berikut:

$$
\begin{aligned}
\mathrm{H} & =21,16-0,805 \\
& =20,35 \mathrm{~m}
\end{aligned}
$$

Segitiga kecepatan didapat dari:

$$
\eta_{0} \cdot \mathrm{g} \cdot \mathrm{H}=\mathrm{u} \cdot\left(\mathrm{V}_{\mathrm{u} 1}-\mathrm{V}_{\mathrm{u} 2}\right)
$$

Dengan $\mathrm{V}_{\mathrm{u} 2}=0$, karena $\mathrm{V}_{2}$ adalah pengeluaran yang tegak lurus maka: 
$\mathrm{V}_{\mathrm{u} 1}$ $=8,05 \mathrm{~m} / \mathrm{det}$

Dengan demikian segitiga kecepatan dapat digambar:

1. Section II (Bagian Tengah Sudu)

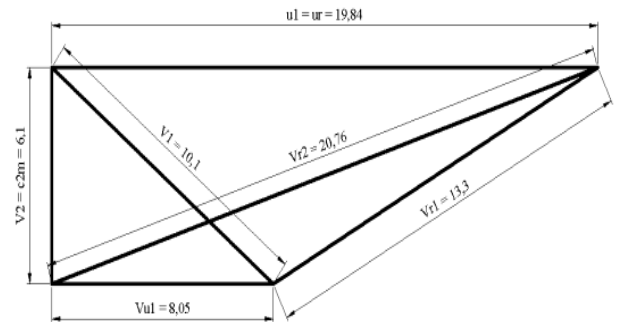

Gambar 5. Segitiga Kecepatan Pada Bagian Tengah Sudu

a) Bagian kecepatan aliran keluar

Dari $\mathrm{u}_{\text {rata-rata }}=19,84 \mathrm{~m} /$ det dan

$$
\begin{gathered}
V_{2}=c_{2} m=c_{2}=\frac{Q}{A} \\
\mathrm{~V}_{2}=\mathrm{c}_{2} \mathrm{~m}=6,10 \mathrm{~m} / \mathrm{det}
\end{gathered}
$$

Maka,

$$
\begin{aligned}
\mathrm{V}_{\mathrm{r} 2} & =20,76 \mathrm{~m} / \mathrm{det} \\
\beta_{2} & =\operatorname{arc} \cdot \sin \frac{6,1}{20,76} \\
& =17,1^{0}
\end{aligned}
$$

b) Segitiga kecepatan aliran masuk Dengan melalui ujung $\mathrm{V}_{2}$ dibuat garis sejajar dengan $\mathrm{u}_{1}$ dan kemudian diukurkan harga $\mathrm{V}_{\mathrm{u} 1}=8,05 \mathrm{~m} /$ det, maka didapat:

$$
\begin{aligned}
\mathrm{V}_{\mathrm{r} 1} & =\sqrt{\left(c_{2} m\right)^{2}+\left(u_{\text {rata-rata }}-V_{u 1}\right)^{2}} \\
\mathrm{~V}_{\mathrm{r} 1} & =13,3 \mathrm{~m} / \mathrm{det} \\
V_{1} & =\sqrt{\left(c_{2} m\right)^{2}+\left(V_{u 1}\right)^{2}} \\
\mathrm{~V}_{1} & =10,10 \mathrm{~m} / \mathrm{det} \\
\beta_{1} & =\operatorname{arcs} \sin \frac{6,1}{10,1} \\
& =37,15^{0}
\end{aligned}
$$

2. Section III (Bagian Lebar Poros)

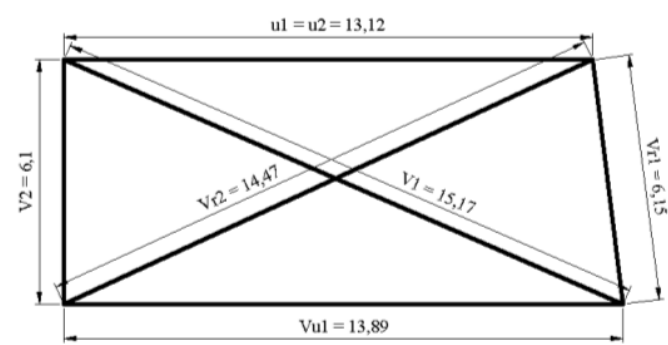

a) Segitiga kecepatan aliran keluar

Dari $\mathrm{u}_{\mathrm{N}}=13,12 \mathrm{~m} / \mathrm{det}$ $\mathrm{c}_{2} \mathrm{~m} \quad=6,10 \mathrm{~m} / \mathrm{det}$

Maka:

$$
\begin{aligned}
& V_{r 2}=\sqrt{\left(c_{2} m\right)^{2}+\left(u_{N}\right)^{2}} \\
& V_{r 2}=\sqrt{\left(c_{2} m\right)^{2}+\left(u_{N}\right)^{2}}
\end{aligned}
$$

$$
\begin{aligned}
& \mathrm{V}_{\mathrm{r} 2}=14,47 \\
& \beta_{2}=\arcsin \frac{6,1}{14,47} \\
& \beta_{2}=24,9^{0}
\end{aligned}
$$

b) Segitiga kecepatan aliran masuk

$$
\begin{aligned}
\mathrm{V}_{\mathrm{u} 1} & =13,89 \mathrm{~m} / \mathrm{det} \\
V_{r 1} & =\sqrt{\left(c_{2} m\right)^{2}+\left(V_{u 1}-u_{N}\right)^{2}} \\
\mathrm{~V}_{\mathrm{r} 1} & =6,15 \mathrm{~m} / \mathrm{det} \\
V_{1} & =\sqrt{\left(c_{2} m\right)^{2}+\left(V_{u 1}\right)^{2}} \\
\mathrm{~V}_{1} & =15,17 \mathrm{~m} / \mathrm{det} \\
\beta_{1} & =90+\arcsin \frac{1,26}{6,1} \\
\beta_{1} & =101,7^{0}
\end{aligned}
$$

\section{Section I (Bagian Ujung Luar)}

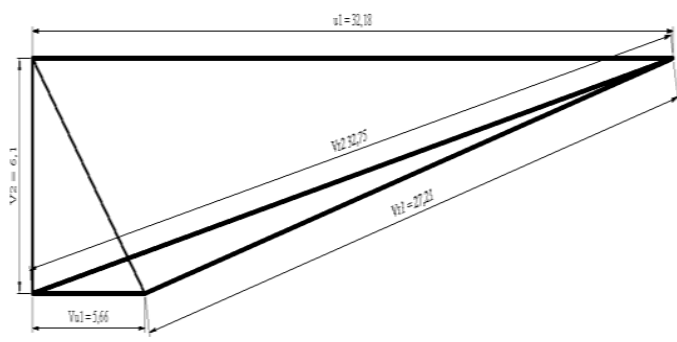

Gambar 7. Segitiga Kecepatan Pada Bagian Ujung Luar

a) Segitiga kecepatan aliran keluar

$$
\begin{aligned}
& V_{r 2}=\sqrt{\left(c_{2} m\right)^{2}+\left(u_{1}\right)} \\
& \mathrm{V}_{\mathrm{r} 2}=32,75 \mathrm{~m} / \mathrm{det} \\
& \beta_{2}=\arcsin \frac{6,1}{32,18} \\
& \beta_{2}=10,73^{0}
\end{aligned}
$$

b) Segitiga kecepatan aliran masuk

$$
\begin{aligned}
& \mathrm{V}_{\mathrm{u} 1}=5,66 \mathrm{~m} / \mathrm{det} \\
& V_{r 1}=\sqrt{\left(c_{2} m\right)^{2}+\left(u_{1}-V_{u 1}\right)^{2}} \\
& \mathrm{~V}_{\mathrm{r} 1}=27,21 \mathrm{~m} / \mathrm{det} \\
& V_{1}=\sqrt{\left(c_{2} m\right)^{2}+\left(V_{u 1}\right)^{2}} \\
& \mathrm{~V}_{1}=8,32 \mathrm{~m} / \mathrm{det} \\
& \beta_{1}=\arcsin \frac{6,1}{27,21} \\
& \beta_{1}=13^{0}
\end{aligned}
$$

\section{Prosedur Pengambilan Data}

Adapun prosedur pengumpulan data antara lain:

- Wawancara dengan Kepala PLTM Plumbungan tentang optimasi instalasi yang nantinya akan dianalisa oleh penulis.

- Studi kasus head dan debit air yang terus menurun. 
- Memahami data-data tentang sudu jalan, spiral casing, draft tube, pipa pesat, poros, bantalan.

\section{Spesifikasi Data}

Dari hasil wawancara data yang diperoleh dokumen data yang sangat minim sekali, antara lain:

$$
\begin{array}{lll}
\text { - Debit Q } & = & 7,68 \mathrm{~m}^{3} / \mathrm{s} \\
\text { - Head H } & = & 21,16 \mathrm{~m} \\
\text { - Berat Jenis Air }(\rho) & = & 1000 \mathrm{~kg} \cdot \mathrm{m}^{3}
\end{array}
$$

\section{Perhitungan Konstruksi Turbin Kaplan}

Perancangan ulang turbin air Kaplan di PLTM Plumbungan meliputi sudu jalan, spiral casing, draft tube, pipa pesat, poros, bantalan. Karena sebab itu perencanaan kali ini menghitung ulang ukuran-ukuran utama turbin jenis Kaplan yang bekerja pada head dan debit yang ada dilapangan yaitu pada head 21,16 m dan debit 7,68 $\mathrm{m}^{3} /$ detik Skema perencanaan adalah sebagai berikut:

a) Menghitung daya turbin

b) Perhitungan penstock

c) Menghitung kecepatan sinkronisasi.

d) Menetukan kecepatan spesifik, dan ukuran-ukuran diameter runner dan runner bos, serta tinggi sudu penggerak.

e) Perhitungan rumah keong

f) Perhitungan draft tube

g) Perhitungan poros

h) Perhitungan bantalan

i) Perhitungan kavitasi

Daya Turbin

Untuk menghitung output turbin, dipakai rumus sebagai berikut :

$$
P t=\frac{\eta \cdot \rho \cdot Q \cdot H}{75}
$$

Dimana :

$$
\begin{array}{ll}
\mathrm{Pt} & =\text { Daya output }(\mathrm{HP}) \\
\eta & =\text { Efisiensi turbin } \\
& =84 \%-94 \% \text { diambil } 94 \%)
\end{array}
$$

Jadi

$$
P t=1,2 M w
$$

\section{Perhitungan Penstock}

Penggunaannya Penstock berdasarkan pada kebutuhan lapangan. Ukuran diameter pipa penstock dapat ditentukan dengan persamaan (Sumber: Warnick, 1984, hal; 127) sebagai berikut:

$$
\begin{aligned}
& D_{p}=0,72 \times 7,68^{0,5} \\
& D_{p}=1,995 \mathrm{~m}
\end{aligned}
$$

Sedangkan, ketebalan dari pipa ditentukan dari persamaan (Sumber: Warnick, 1984, hal: 127) dibawah ini:

$$
\begin{aligned}
t_{\text {min }} & =\frac{D_{p}+20}{400} \\
t_{\text {min }} & =55 \mathrm{~mm}
\end{aligned}
$$

\section{Rumah Keong (Spiral Casing)}

Dalam hal ini yang digunakan dalam perencanaan spiral casing dianggap sama dengan yang digunakan pada PLTM Plumbungan yaitu dengan plat baja tebal 12-20 mm Baja Siemens Martin S55C (Sumber: PLTA PB. Soedirman) yang sudah ada dipabrikan, dilas satu sama lain sehingga berbentuk spiral.

Selubung scroll terdiri dari $2 \times 21$ buah plat baja dengan tebal $12-20 \mathrm{~mm}$ bahannya adalah Baja Siemens Martin S55C. Merencanakan ukuranukuran dari rumah keong dalam hal ini $\mathrm{D}=1230$ $\mathrm{mm}$ dan kecepatan spesifiknya $\mathrm{N}_{\mathrm{s}}=144,62 \mathrm{rpm}$.

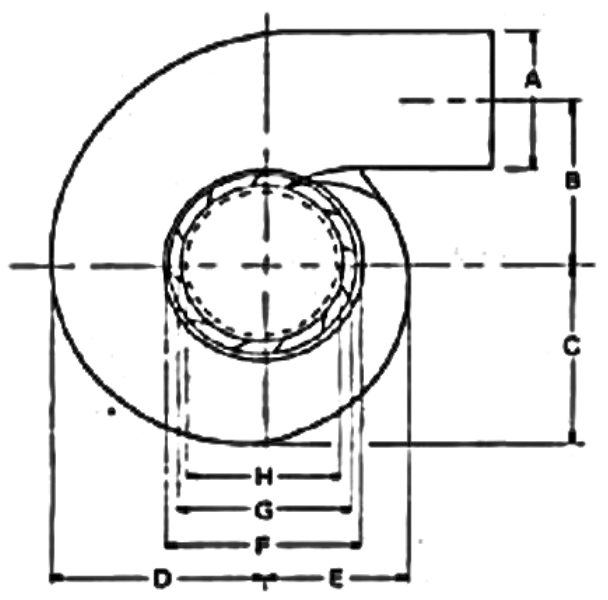

Gambar 8. Pandangan Atas Spiral Casing

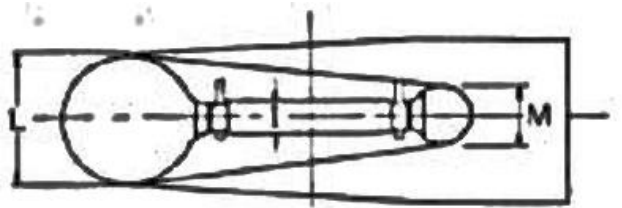

Gambar 9. Pandangan Samping Spiral Casing

Karena penampang spiral casing berbentuk lingkaran, maka untuk mempermudah perhitungan maka digunakan pendekatan dengan rumus empiris yang terdapat pada literatur yang penulis miliki.

a). Spiral Casing Dari Pandangan Atas:

Ukuran pada bagian A (m) spiral casing (Sumber: Warnick, 1984, hal; 136) yaitu:

$$
\begin{aligned}
& \frac{A}{D}=1,2-\left[\frac{19,5}{N_{s}}\right] \\
& \mathrm{A}=1,310 \mathrm{~m} \\
& \mathrm{~A}=1310 \mathrm{~mm}
\end{aligned}
$$

Ukuran pada bagian B (m) spiral casing: 


$$
\begin{aligned}
& \frac{B}{D}=1,1+\left[\frac{54,8}{N_{s}}\right] \\
& \mathrm{B}=1,819 \mathrm{~m} \\
& \mathrm{~B}=1819 \mathrm{~mm}
\end{aligned}
$$

Ukuran pada bagian $\mathrm{C}(\mathrm{m})$ spiral casing:

$$
\begin{aligned}
& \frac{C}{D}=1,32+\left[\frac{49,25}{N_{s}}\right] \\
& \text { B }=2042 \mathrm{~mm}
\end{aligned}
$$

Ukuran pada bagian D $(\mathrm{m})$ spiral casing:

$$
\begin{aligned}
& \frac{D}{D}=1,50+\left[\frac{48,8}{N_{s}}\right] \\
& \mathrm{D}=1,746 \mathrm{~m} \\
& \mathrm{D}=1746 \mathrm{~mm}
\end{aligned}
$$

Ukuran pada bagian E (m) spiral casing:

$$
\begin{aligned}
& \frac{E}{D}=0,98+\left[\frac{63,60}{N_{s}}\right] \\
& \mathrm{E}=1,746 \mathrm{~m} \\
& \mathrm{E}=1746 \mathrm{~mm}
\end{aligned}
$$

Ukuran pada bagian $\mathrm{F}(\mathrm{m})$ spiral casing:

$$
\begin{aligned}
& \frac{F}{D}=1+\left[\frac{131,4}{N_{s}}\right] \\
& \mathrm{E}=2,348 \mathrm{~m} \\
& \mathrm{~B}=2348 \mathrm{~mm}
\end{aligned}
$$

Ukuran pada bagian $\mathrm{G}(\mathrm{m})$ spiral casing:

$$
\begin{aligned}
& \frac{G}{D}=0,89+\left[\frac{96,5}{N_{s}}\right] \\
& \mathrm{G}=1,915 \mathrm{~m} \\
& \mathrm{G}=1915 \mathrm{~mm}
\end{aligned}
$$

Ukuran pada bagian $\mathrm{H}(\mathrm{m})$ spiral casing:

$$
\begin{aligned}
& \frac{H}{D}=0,79+\left[\frac{81,75}{N_{s}}\right] \\
& \mathrm{H}=1,667 \mathrm{~m}=1667 \mathrm{~mm}
\end{aligned}
$$

b). Spiral Casing Pandangan Samping

Ukuran pada bagian I (m) spiral casing:

$$
\begin{aligned}
& \frac{I}{D}=0,1+\left(0,00065 \times N_{s}\right) \\
& \mathrm{I}=0,239 \mathrm{~m} \\
& \mathrm{I}=239 \mathrm{~mm}
\end{aligned}
$$

Ukuran pada bagian $\mathrm{M}(\mathrm{m})$ spiral casing:

$$
\begin{aligned}
& \frac{M}{D}=0,60+\left(0,000015 \times N_{s}\right) \\
& \mathrm{M}=1,170 \mathrm{~m} \\
& \mathrm{M}=1170 \mathrm{~mm}
\end{aligned}
$$

Ukuran pada bagian L (m) spiral casing:

$$
\begin{aligned}
& \frac{L}{D}=0,88+\left(0,00049 \times N_{s}\right) \\
& \mathrm{L}=1,170 \mathrm{~m} \\
& \mathrm{~L}=1170 \mathrm{~mm}
\end{aligned}
$$

\section{Perhitungan Poros}

Poros merupakan salah satu bagian terpenting dari setiap mesin yang berfungsi untuk meneruskan tenaga bersama-sama dengan putaran. Poros bisa menerima beban berupa lenturan, tarikan, tekan, atau puntiran yang bekerja sendiri-sendiri atau gabungan satu dengan lainnya.

Pada turbin Kaplan poros berfungsi sebagai penerus putaran runner ke generator. Diambil data:

$$
\begin{aligned}
& \mathrm{P}=1,2 \mathrm{MW} \\
& \mathrm{N}_{1}=500 \mathrm{rpm}
\end{aligned}
$$

Apabila $\mathrm{P}$ adalah daya nominal output dari turbin maka berbagai macam faktor keamanan biasanya dapat diambil dalam perencanaan. Sehingga koreksi pertama dapat diambil kecil. Faktor koreksi $f_{c}$ dapat dilihat pada tabel Faktor Koreksi Daya Yang Ditransmisikan. Perhitungan untuk daya rencana (Sumber: Sularso \& Kiyokatsu, 1995, hal: 7) adalah sebagai berikut:

$$
\begin{aligned}
& \mathrm{P}_{\mathrm{d}}=f_{c} . \mathrm{P} \\
& \mathrm{P}_{\mathrm{d}}=2800 \mathrm{~kW}
\end{aligned}
$$

1. Momen Puntir (Torsi)

Momen puntir yang bekerja pada poros adalah $T$ (kg.mm), maka:

$$
\begin{aligned}
& T=9,74 \times 10^{5} \frac{P_{d}}{N_{1}} \\
& T=5454400 \mathrm{~kg} / \mathrm{mm}
\end{aligned}
$$

Bahan poros yang direncanakan adalah baja paduan yaitu baja khrom nikel (JIS G 4102), SN C21 dengan perlakuan panas (pengerasan kulit), memiliki kekuatan tarik $\sigma_{\mathrm{B}}=80 \mathrm{~kg} / \mathrm{mm}^{2}$ diperoleh dari tabel Bahan Baja Paduan Untuk Poros. Faktor keamanan pada poros:

$$
\begin{aligned}
& \mathrm{S} f_{1}=6.0 \\
& \mathrm{~S} f_{2}=1.3-3.0
\end{aligned}
$$

2. Momen Lengkung Pada Poros

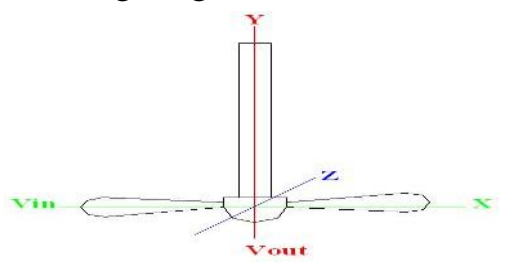

Gambar 12. Gaya Pada Poros

$$
\begin{aligned}
\mathrm{V}_{\text {in }} & \mathrm{V}_{\text {out }} \\
\mathrm{V}_{\mathrm{x}}=\mathrm{V}_{\text {in }} & \mathrm{V}_{\mathrm{y}}=\mathrm{V}_{\text {out }} \\
\mathrm{V}_{\mathrm{y}}=0 & \mathrm{~V}_{\mathrm{x}}=0 \\
\mathrm{~V}_{\mathrm{z}}=0 & \mathrm{~V}_{\mathrm{z}}=0
\end{aligned}
$$

Terjadi perubahan momentum yaitu:

$$
\begin{aligned}
& \mathrm{F} . \mathrm{t}=\Delta(\mathrm{m} . \mathrm{V}) \\
& \mathrm{F} . \mathrm{t}=\mathrm{m} . \Delta \mathrm{V} \\
& \mathrm{F}=\mathrm{Q} .\left(\mathrm{V}_{\text {out }}-\mathrm{V}_{\text {in }}\right)
\end{aligned}
$$

Karena perubahan kecepatan pada sumbu $\mathrm{Z}$ tidak ada maka $\mathrm{F}_{\mathrm{z}}=0$, jadi:

$$
\begin{aligned}
& \mathrm{F}=\mathrm{Q} \cdot\left(0-\mathrm{V}_{\text {in }}\right) \\
& \mathrm{F}=7,68 \cdot(0-8,32) \\
& \mathrm{F}=-63,9 \text { (reaksi terhadap arah aliran } \\
& \text { air) }
\end{aligned}
$$


Momen lengkung pada poros adalah:

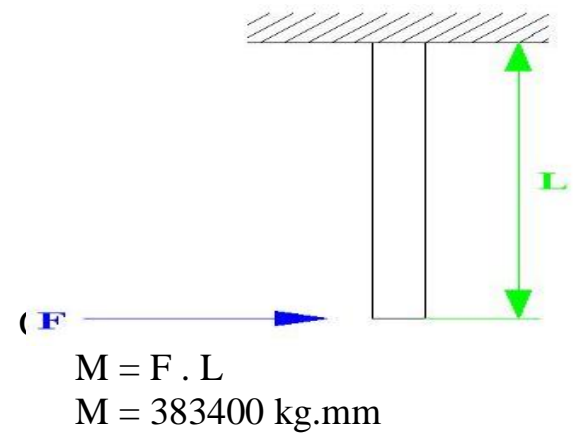

3. Tegangan Geser Pada Poros

Tegangan geser yang diijinkan

(Sumber: Sularso \& Kiyokatsu, 1978, hal:

7), yaitu:

$$
\begin{aligned}
\sigma_{a} & =\frac{\sigma_{B}}{\left(S f_{1} \times S f_{2}\right)} \\
\sigma_{a} & =4,4444 \mathrm{~kg} / \mathrm{m}^{2}
\end{aligned}
$$

4. Diameter Poros

Maka diameter porosnya $\mathrm{d}_{\mathrm{s}}(\mathrm{mm})$

(Sumber: Sularso \& Kiyokatsu, 1995, hal:

$8)$, adalah sebagai berikut:

$$
d s \geq\left[\left(\frac{5,1}{\tau_{a}}\right) \sqrt{(K m \cdot M)^{2}+(K t \cdot T)^{2}}\right] 1 / 3
$$

Dalam hal ini,

$$
\begin{gathered}
\mathrm{K}_{\mathrm{t}}=\text { Faktor koreksi yang bernilai: } \\
\quad 1,0-1,5 \text { (sedikit kejutan) } \\
\mathrm{K}_{\mathrm{m}}= \\
\text { Faktor pembebanan lentur: } \\
1,5-2,0 \text { (sedikit kejutan) }
\end{gathered}
$$

Jadi, diameter minimum poros:

$$
\mathrm{d}_{\mathrm{s}}=250 \mathrm{~mm}
$$

\section{ANALISA DAN PEMBAHASAN}

Dari hasil pengolahan data serta perhitunganperhitungan diatas, daya terpasang sebesar $1,2 \mathrm{Mw}$, head maksimal 21,16 meter dan kebutuhan debit air sebesar 7,68 $\mathrm{m}^{3} /$ detik, dengan kondisi lokasi ketika maksimal $8 \mathrm{~m}^{3} /$ detik, normal 7,89 $\mathrm{m}^{3} /$ detik, dan minimal $7,34 \mathrm{~m}^{3} /$ detik. Turbin dapat beroperasi secara maksimal.

\section{Analisa Head Loss}

Adanya alir melalui pipa penyalur (penstock) akan mengakibatkan terjadinya kerugian pada ketinggian (head losses).

- Head loss pada trash rach

- Head loss pada entrance

- Head loss akibat penyempitan pipa

- Head loss akibat friction

- Head loss pada elbow

- Head loss pada katup

Total Head loss yang terjadi:

Head loss $_{\text {total }}=0,805 \mathrm{~m}$

\section{Analisa Kecepatan Singkron}

PLTM Plumbungan mempunyai generator dengan 12 kutub (6 pasang kutub) dan digunakan untuk mensuplai jaringan dengan frekuensi $50 \mathrm{~Hz}$. Sehingga putaran singkron generator dan turbin adalah: $\mathrm{n}=500 \mathrm{rpm}$

Kecepatan aliran turbin kaplan di PLTM Plumbungan tertera pada name plate sebesar 1400 rpm, dan bila dibandingkan dengan kecepatan normalnya maka terjadi kenaikan sebesar $280 \%$, sesuai dengan tabel dari kecepatan liar harga ini masih dapat diterima untuk turbin Kaplan.

\section{KESIMPULAN}

Kesimpulan yang didapat dari hasil perencanaan ini adalah

1. Turbin Kaplan mempunyai keistimewaan yaitu sudut sudu geraknya (runner) bisa diatur dengan (adjustable blade) untuk menyesuaikan dengan aliran saat itu, yaitu perubahan debit air.

2. Pada dasarnya pemilihan tipe turbin untuk Pembangkit Listrik Tenaga Minihidro (PLTM) sama dengan pada turbin PLTA konvensional. Dasar tipe turbin adalah besaran head (meter), debit air $\left(\mathrm{m}^{3} /\right.$ detik), dan besarnya kecepatan putar turbin (n).

3. Kecepatan putaran rencanakan setinggi mungkin, karena dengan kecepatan putar yang tinggi akan didapat momen punter yang kecil, poros yang kecil, dan diameter rodaturbin yang kecil juga, sehingga akan membuat ukuran generator lebih kecil.

\section{DAFTAR PUSTAKA}

Banga \& Sharma., Hydraulik Machines, Khuaum Publisher, Delhi, India.

Dake JMK., 1985, Hydraulika Teknik, Erlangga, Jakarta.

Dandekar\& Sharma, 1979 "Water Power Engineering", Viskositas Publishing PVT Ltd., New Delhi.

Fritz Dietsel, 1996, Turbin, Pompa dan Kompresor, Penerbit Erlangga, Jakarta

J.K.Gupta,1995, Machine Design, Eurasia Publishing House (Pvt) LTD Ram Nagar, New Delhi.

Joseph E Shigley, 2001, Mechanical Engineering Design, Sixth Edition, Penerbit McGraw-Hill, New York.

Kamimoto Goro \& Hisashi Ando \& Akamatsu Teruaki, 2001 "Analisis Aliran Dalam Turbin Air Tipe Aliran Aksial"termuat di: www.educepedia.be/education/physicsenergyh ydro.htm diakses 23 Juni 2010.

Lal Jagdish., 1975, Hydraulic Machine, McGrawHill, Delhi, India. 
G. Niemann, 1990, Desain dan Kalkulasi dari Sambungan, Bantalan, dan Poros, Penerbit Erlangga, Jakarta.

PLN Sektor Mrica, PLTA PB. Soedirman, "Petunjuk Operasi dan Pemeliharaan Turbin, Katup dan Peralatan Bantu", Bogor.

Rifai, 2000, Perancangan Turbin Air Kaplan, IST Akprind, Yogyakarta.

Rubianto, 2006, Perancangan Ulang Runner Turbin Air Jenis Kaplan Dengan Daya 6,5 MW Pada PLTA Wonogiri, IST Akprind, Yogyakarta.

S, Radler Prof. Dr., 1981, "Desaign Runner Of Kaplan Turbin", Intitute for Water Management, University for Soil Culture, Vienna.

Subhan Nafis. 2005. "Dasar Perencanaan PLTMH". Jurnal Institut Teknologi Surabaya, Surabaya termuat di: www.wikipedia.com diakses 21 Juni 2010.

Sularso \& Kyokatsu, 1995, Dasar-Dasar Perencanaan Mesin, Cetakan ke-sembilan, Penerbit Pradnya Paramita, Jakarta.

Sujatmika \& Denny Agung, 2008, "Perencanaan Turbin Kaplan", Jurnal Institut Teknologi Surabaya, Surabaya termuat di: www.wikipedia.com diakses 23 Juni 2010.

W. Arismunandar, Penggerak Mula Turbin, Penerbit Erlangga, Jakarta

Warnick C.C., 1984, Hydropower Engineering, Professor of Civil Engineering, University of Indaho Moscow, Indaho. 